\title{
Responses of snowmelt runoff to climatic change in an inland river basin, Northwestern China, over the past 50 years
}

\author{
J. Wang, H. Li, and X. Hao \\ Cold and Arid Regions Environmental and Engineering Research Institute, Chinese Academy of Sciences, \\ Lanzhou, 730000, China \\ Received: 18 December 2009 - Published in Hydrol. Earth Syst. Sci. Discuss.: 21 January 2010 \\ Revised: 2 September 2010 - Accepted: 6 October 2010 - Published: 19 October 2010
}

\begin{abstract}
The spatial and temporal variations of snowcover distribution, and snowmelt runoff are considered as sensitive indicators for climatic change. The purpose of this paper is to analyze and forecast the responses of snowmelt runoff to climate change in an inland river basin. The upper basin of Heihe River in Northwestern China was chose as the study area, and the observation data from the meteorological and hydrological stations were utilized to analyze the status and regularity of the climatic change over the past 50 years. Snow cover area was obtained by an optimized technology using Moderate Resolution Imaging Spectroradiometer data with Normalized Difference Snow Index adjustment and topographic correction. A concept of potential snowmelt was suggested to illustrate the response of spatial snowmelt to climate change. The results show that the annual SCA proportion and the potential snowmelt keep an increasing trend since 2000. There is a negative relationship between annual air temperature and SCA proportion from 2000 to 2008. Snowmelt Runoff Model was chose to simulate snowmelt runoff and scenario forecast the change trend of snowmelt runoff in this region. The results show that climatic warming was apparent in the upper basin of Heihe River over the past $50 \mathrm{a}$. Annual average air temperature of three different weather stations located in the basin has increased $2.1{ }^{\circ} \mathrm{C}, 2.6^{\circ} \mathrm{C}$ and $2.9^{\circ} \mathrm{C}$ respectively from 1956 to present. The snowmelt runoff has increased obviously from 1970 to present. With different warming climate scenarios, the results by using SRM simulating showed that the first occurred time of snowmelt runoff shift ahead and discharge become larger as responses of snowmelt runoff to air temperature increasing, and the influence of temperature rising on average discharge of the whole snow season is not obvious.
\end{abstract}

Correspondence to: J. Wang

(wjian@lzb.ac.cn)

\section{Introduction}

It was highlighted in IPCC reports (Solomon and Qin, 2007), that the global average surface temperature had a rise of $0.74{ }^{\circ} \mathrm{C}$ over the past 100 years. Global climate change had lead to the variation of snow cover distribution and snowmelt runoff regime in different scales, and also this variation will affect the management of snowmelt water resource for the watershed. Many studies indicate that rising of temperature has caused redistribution and trended variations of snowcover at watershed scales in the Northern Hemisphere, High Asia, and mid-latitude mountains (McCabe and Wolock, 2009; López-Moreno et al., 2009). Responses of water resources supply to climate change is the most important issue in recent studies. These studies confirm that the discharge regime in snowmelt-dominated river basins is most sensitive to temperature increases in snow season (Rauscher et al., 2008; Adam et al., 2009; Day, 2009; Stewart et al., 2004). The earlier occurring of spring snowmelt runoff had been observed in many watersheds around the world (Bates, 2008; Lemke et al., 2007).With more than one-sixth of the Earth's population relying on glaciers and seasonal snowpacks for their water supply, it is still needed to diagnose and predict the consequences of these hydrological changes for future water availability (Barnett et al., 2005).

Snow accumulation, distribution and ablation were surely affected by climate change in Northwestern China. As the most important water resources in inland river basin such as Heihe River basin in China, snowmelt runoff had received greater attention (Wang and Wang, 2003). The changes of snowmelt runoffs will directly affect strategies and polices of water resources management, socio-economic development, industry and ecological environment (Wang and $\mathrm{Li}, 2006$ ). Then, it is the most compelling need to study the response of snowmelt runoff to climatic change in northwestern China.

Published by Copernicus Publications on behalf of the European Geosciences Union. 


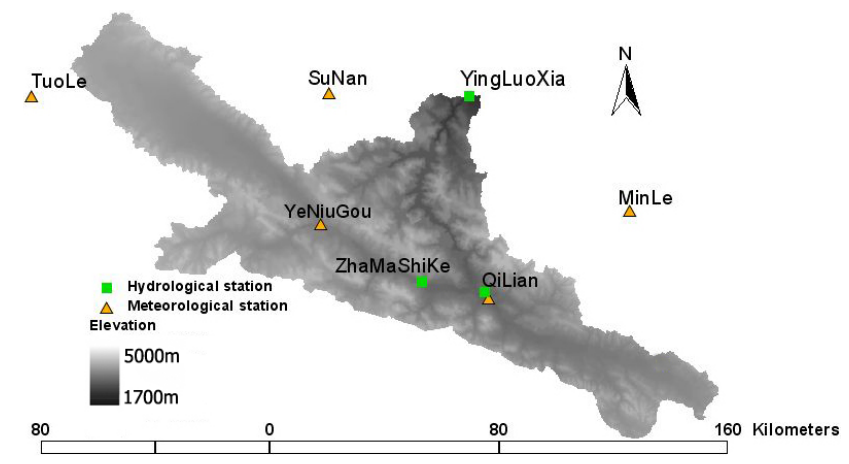

Fig. 1. Locations of weather stations, hydrological stations, and DEM of the upper basin of Heihe River.

The purpose of this article is to evaluate the responses of snowcover and snowmelt runoff to the climatic change, to simulate and forecast the change trend of snowmelt runoff for the mountainous region in Northwestern China.

\section{Study area and data}

The upper basin of Heihe River in northwestern China, was chose as the study area (Fig. 1), because of its typical topography, climate, and environmental conditions. It is the second largest inland river basin over China. Although Heihe River basin is in the arid area, the upper reaches of it has rich snow water resources. The water supplies for the upper Heihe Watershed include snow- and ice-melt water, ground water and precipitation. The rainfall of the upper basin of Heihe River concentrates in summer, accounting for $61 \%-81 \%$ of annual total precipitation. However there is only $19 \%$ of annual total precipitation in spring season from March to June when the demands for agricultural irrigation are strongest. During this period, $70 \%$ of runoffs are supplied by snowmelt water (Wang and Li, 2001). Therefore, snowmelt and its variability will directly and remarkably affect the water supplies for agriculture, industry, and livestock in the middle and down streams of the Heihe River basin. Climate change especially temperature increasing had greatly affected runoff in Heihe River basin recently. Overall, the upper basin of Heihe River is a typical inland river basin with seasonal snowpack, it is important to research the responses of air temperature, precipitation and runoff to climate change, and understand the inherent law of snowmelt runoff in the climate change scenario.

The basin area is about $10009 \mathrm{~km}^{2}$, with an altitude range from $1674 \mathrm{~m}$ to $5108 \mathrm{~m}$. Temporary snow usually exists under $2700 \mathrm{~m}$, patchy snowpack is in range from $2700 \mathrm{~m}$ to $3400 \mathrm{~m}$ continues and durative snowpack exists above $3400 \mathrm{~m}$; Alpine steppe and desert steppe exists under $2800 \mathrm{~m}$, alpine meadow and bushes is in range from $4000 \sim 2800 \mathrm{~m}$, bare ground exists above $4000 \mathrm{~m}$ (Wang and Li, 2006). For
Table 1. Elevation zones and areas of the upper basin of Heihe River.

\begin{tabular}{lrrc}
\hline Elevation zone & Elevation range/m & Area/km & Average Elevation $/ \mathrm{m}$ \\
\hline A & $1700 \sim 2700$ & 423.49 & 2456 \\
B & $2700 \sim 3400$ & 2195.44 & 3156 \\
C & $3400 \sim 4000$ & 4641.18 & 3719 \\
D & $4000 \sim 5108$ & 2748.89 & 4196 \\
Whole Basin & $1700 \sim 5108$ & 10009.00 & - \\
\hline
\end{tabular}

Table 2. Basic information of meteorological stations in the upper basin of Heihe River.

\begin{tabular}{lrrrrc}
\hline Station & Longitude & latitude & $\begin{array}{c}\text { elevation/ } \\
\mathrm{m}\end{array}$ & $\begin{array}{c}\text { Air } \\
\text { temperature/ } \\
{ }^{\circ} \mathrm{C}\end{array}$ & $\begin{array}{c}\text { Annual } \\
\text { precipitation/ } \\
\mathrm{mm}\end{array}$ \\
\hline MinLe & $100^{\circ} 49^{\prime}$ & $38^{\circ} 27^{\prime}$ & 2271 & 3.4 & 335.4 \\
SuNan & $99^{\circ} 37^{\prime}$ & $38^{\circ} 48^{\prime}$ & 2312 & 3.9 & 250.8 \\
QiLian & $100^{\circ} 14^{\prime}$ & $38^{\circ} 12^{\prime}$ & 2787 & 1.1 & 395.6 \\
YeNiuGou & $99^{\circ} 36^{\prime}$ & $38^{\circ} 24^{\prime}$ & 3180 & -2.9 & 376.6 \\
TuoLe & $98^{\circ} 24^{\prime}$ & $38^{\circ} 48^{\prime}$ & 3360 & -2.5 & 259.4 \\
\hline
\end{tabular}

this study, the basin was segmented as four elevation zones (A, B, C, and D) (Table 1).

There are 5 meteorological stations (MinLe, SuNan, QiLian, YeNiuGou, TuoLe) and 2 hydrological stations (ZhaMaShiKe, YingLuoXia) distributed in and around the basin as Table 2 shows. Data from these stations were used to analyze the responses of snowmelt runoff to climate change.

Snow Cover Area (SCA) is the key feature for describing the snow distribution and it is also the basic input to the snowmelt runoff model. The MODIS snow products which have been freely available (Hall et al., 2002; Riggs et al., 2006), were used to produce SCA data. Using Terra MODIS Surface Reflectance data (MOD09) from 26 February 2000 to 16 October 2009, we retrieved a series of SCA data of the upper basin of Heihe River. The SCA data were used to analyze the snow cover change and drive modeling climate change scenario.

\section{Method}

\subsection{Snow cover mapping}

Many results have testified that MODIS snow cover products distributed by National Snow and Ice Data Center (NSIDC) agrees well with field observations, and the overall agreement is about $80-100 \%$ in flat topography (Klein and Barnett, 2003; Hall and Riggs, 2006). The MODIS snow cover products algorithm is based on the evaluation of the Normalized Difference Snow Index (NDSI). However, it was found the MODIS snow products underestimated the snow cover area in Northwestern China (Hao et al., 2009). There are two 
main reasons for it, (1) the snow pixel shaded by surrounding terrains can not be identified in MODIS snow products, due to the effects of topography; (2) snowpack is thin and patchy in mountainous region, this characteristics affect the distinguishing between snow and free snow pixel. So we used an improved CIVCO model to eliminate terrain effect (Civco, 1989; Law and Nichol, 2004), and adjust the NDSI threshold value for a better accuracy of SCA.

The prototype snow cover mapping algorithm (Fig. 2), considered the effect of atmospheric and topographic conditions and improved the NDSI threshold value on the upper basin of Heihe River.

\subsubsection{Terrain effect elimination}

The improved CIVCO model inputs include the solar azimuth and altitude provided by the metadata of the satellite image, and the shaded relief image computed using the Digital Elevation Model (DEM) data. The resulting shaded relief model would have values between 0 and 1 . Then, a transformation of each original bands of the satellite image is performed to derive topographically normalized images.

\subsubsection{Adjustment of the NDSI threshold value}

In general, the NDSI is calculated using reflectance in MODIS band 4 and 6,

NDSI $=\frac{\text { band } 4-\text { band6 }}{\text { band } 4+\text { band } 6}$

The NDSI threshold value of the MODIS snow cover products distributed by the NSIDC is 0.40 . However, the validation of this value has being accomplished only by the measurements in the United States and Europe. In China, there is not reliable NDSI threshold value for mapping the MODIS snow cover area. In the study, the Landsat-ETM+ snow cover maps with $30 \mathrm{~m}$ resolution, which were produced by a method named SNOMAP (Hall et al., 1995), were used to validate the MODIS snow cover data. By comparisons between the MODIS snow cover map with different NDSI threshold values and the Landsat-ETM+ snow cover map which are regarded as a relative ground truth, we found the relevant NDSI threshold is about 0.36 for the study area. With this new threshold value, more accuracy SCA data of the study area can be produced.

\subsection{Potential snowmelt}

In general, MODIS daily snow cover maps were affected heavily by clouds. The temporal change of SCA could not be obtained using MODIS daily snow cover maps due to the influence of clouds. So the 8-day composite maximum snow cover maps were obtained based on series of daily MODIS snow cover map. A pixel is to be identified as the snow pixel in which snow appears at least one day during the period

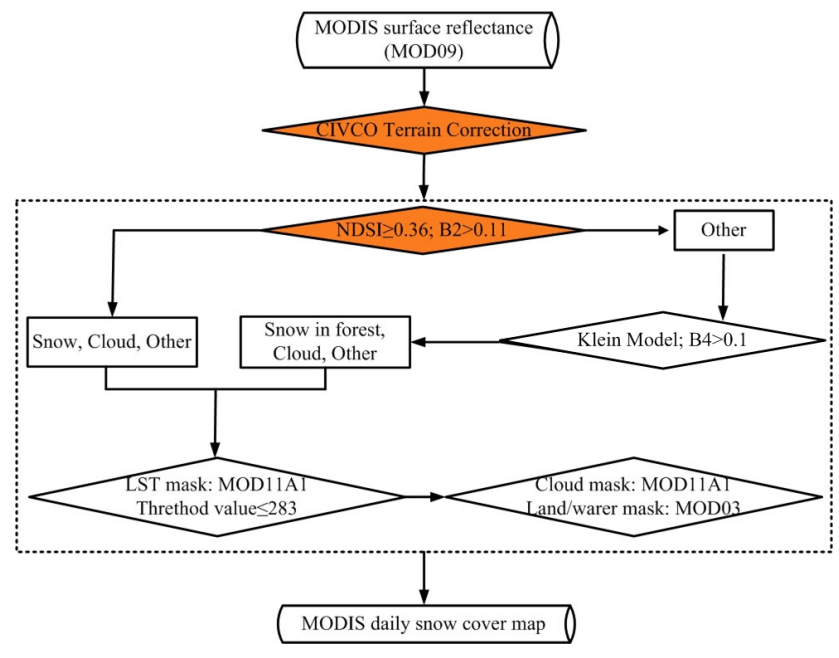

Fig. 2. The flow process of MODIS daily snow cover map algorithm.

of whole 8 days. With the composition, there is almost no clouds influence on the SCA data.

Snowmelt runoff is decided by snowpack and climatic conditions. Individual analysis of SCA cannot make clear the snowmelt responses to climate change. Since air temperature is the major driving factor in some degree-day snow model (Martinec et al., 2005), we define a concept of potential snowmelt $\left(S_{\mathrm{p}}\right)$ to describe the snowmelt change in recent years,

$S_{\mathrm{p}}=a \times \mathrm{SCA} \times\left(T-T_{\mathrm{S}}\right)$

In which, $a$ is the degree-day factor which its value was given monthly. SCA is the snow cover area. $T$ is the air temperature, and $T_{\mathrm{S}}$ is the critical temperature of snowmelt occurrence $\left(0^{\circ} \mathrm{C}\right)$. For meeting the $500 \mathrm{~m}$ resolution of MODIS SCA data, the DEM with the same resolution was used. Air temperature was extrapolated with the lapse rate $\left(0.65^{\circ} \mathrm{C} / 100 \mathrm{~m}\right)$. Because 8-days composite data was used in this article, we define $T$ as the average value of 8-days air temperature. If the air temperature at one grid is less than $0^{\circ} \mathrm{C}$, it is assumed there is no snowmelt occurrence.

We computed the annual potential snowmelt from 2000 to 2008 , and the results were compared with annual air temperature and SCA change.

\subsection{Scenario simulation using SRM model}

Snowmelt Runoff Model (SRM) is designed to simulate and forecast daily runoff in mountainous basins where snowmelt is a major runoff component and it has also been applied to evaluate the effect of the changed climate on seasonal snow cover and runoff (Martinec et al., 2005). Nowadays, with advancing RS snow mapping technology the model has been applied over 100 basins. An obvious trend is using SRM to 


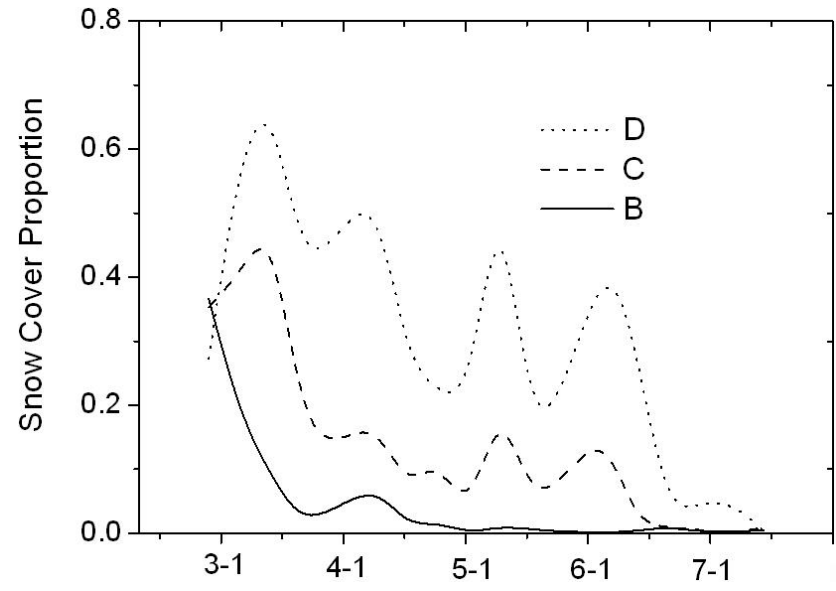

Fig. 3. Depletion curves of the snow coverage for the elevation zones in the upper basin of Heihe River during the snowmelt season in 2004.

model response of runoff to climate change. The fundamental principle of SRM is to use degree-day factor algorithm as snow melt constraint, and to obtain the ratios of snow cover at watershed scale using remote sensing data, to assess discharge (Wang and Li, 2006).

The primary parameters of SRM include the SCA from satellite data, meteorological and hydrological data, and some other parameters such as the temperature lapse rate, degree-day factor and recession coefficient. There were detailed description and particular choice for these parameters in the past literature (Tekeli et al., 2005). SCA depletion curves were interpolated from periodical snow cover mapping of MODIS which produced by the new SCA mapping algorithm with topographic correction and NDSI threshold value adjustment. The transitory new snow was accounted for as stored precipitation eventually contributing to runoff. The depletion curves of snow cover area are showed as Fig. 3 . The zone A is almost no snow existence over the whole snow season.

\section{Results and discussion}

\subsection{Climate change and responses of snowmelt runoff}

Air temperature has gradually increased with fluctuation over the past 50 years, which indicated by the change of the average annual air temperatures of the weather stations (Fig. 4). This increase trend is slow from 1956 to 1980 but enlarged after 1980a. At SuNan (2312 m) and MinLe (2271 m) stations located at lower altitudes, air temperature changes are similar with each other in the past. In this region, air temperature had an increase about $3^{\circ} \mathrm{C}$ since 1980 , and the average annual temperature had reached $4.5^{\circ} \mathrm{C}$ in the recent 10 years; climate conditions of middle zones of the basin

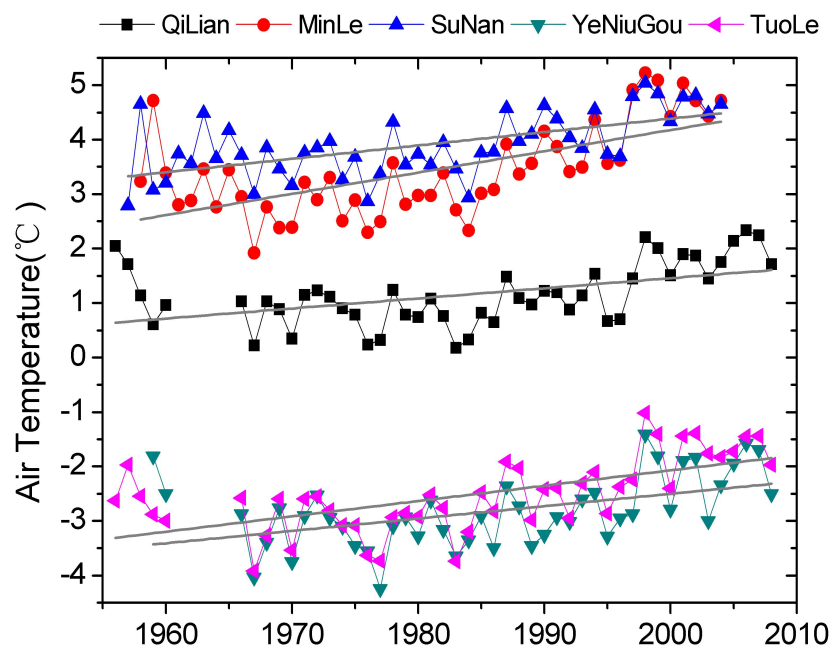

Fig. 4. Annual air temperatures of weather stations over the past 50 years.

could be represented by QiLian station $(2787 \mathrm{~m})$ which temperature change trend is similar with TuoLe Station $(3360 \mathrm{~m})$ at a higher altitude. The air temperature had changed a little in 1950s, but changed significantly after 1980s. Average air temperature of QiLian station had been greater than $1{ }^{\circ} \mathrm{C}$ in the past 12 years while it fluctuated around $1{ }^{\circ} \mathrm{C}$ before. Average air temperature had also increased to $-2{ }^{\circ} \mathrm{C}$ in the past 10 years. The difference between maximum and minimum air temperature over the past 50 years, is about $2.1^{\circ} \mathrm{C}$ at Qilian station, $2.6^{\circ} \mathrm{C}$ at YeNiuGou station and $2.9^{\circ} \mathrm{C}$ at TuoLe station.

Annual precipitations of these five meteorological stations varied from $250.8 \mathrm{~mm}$ to $395.6 \mathrm{~mm}$ as Fig. 5 shows. There are different increases ratios of precipitations at the five stations, in which the rising trends are more obviously at TuoLe and YeNiuGou station. Spring and autumn snowfall were summed as the total snowfall each year. The increasing trends of snowfall of these stations are close to each other in the past 50 years, in which the most obvious increase was from 1977 to 1986 with an increase of $100 \mathrm{~mm}$. In recent 20 years, the increasing trend of snowfall is less obvious but with a large fluctuation about $70 \mathrm{~mm}$.

YingLuoXia station is the control section of the upper basin of Heihe River. The discharge increased slowly from 1945 to $2008 \mathrm{a}$, the minimum is $32.4 \mathrm{~m}^{3} / \mathrm{s}$ of 1973 and the maximum is $73 \mathrm{~m}^{3} / \mathrm{s}$ of 1989 (Fig. 6). The maximum monthly average discharge usually occurred at July or August, contributed mostly by rainfall (Fig. 7). By comparison of monthly discharge change in different years, it is found that the discharge in 1970s is lower than the other years, with a lower annual precipitation and lower average annual air temperature (Figs. 4 and 5).

Snowmelt runoff of March and April increased obviously and peak discharge is earlier than ever before in recent 


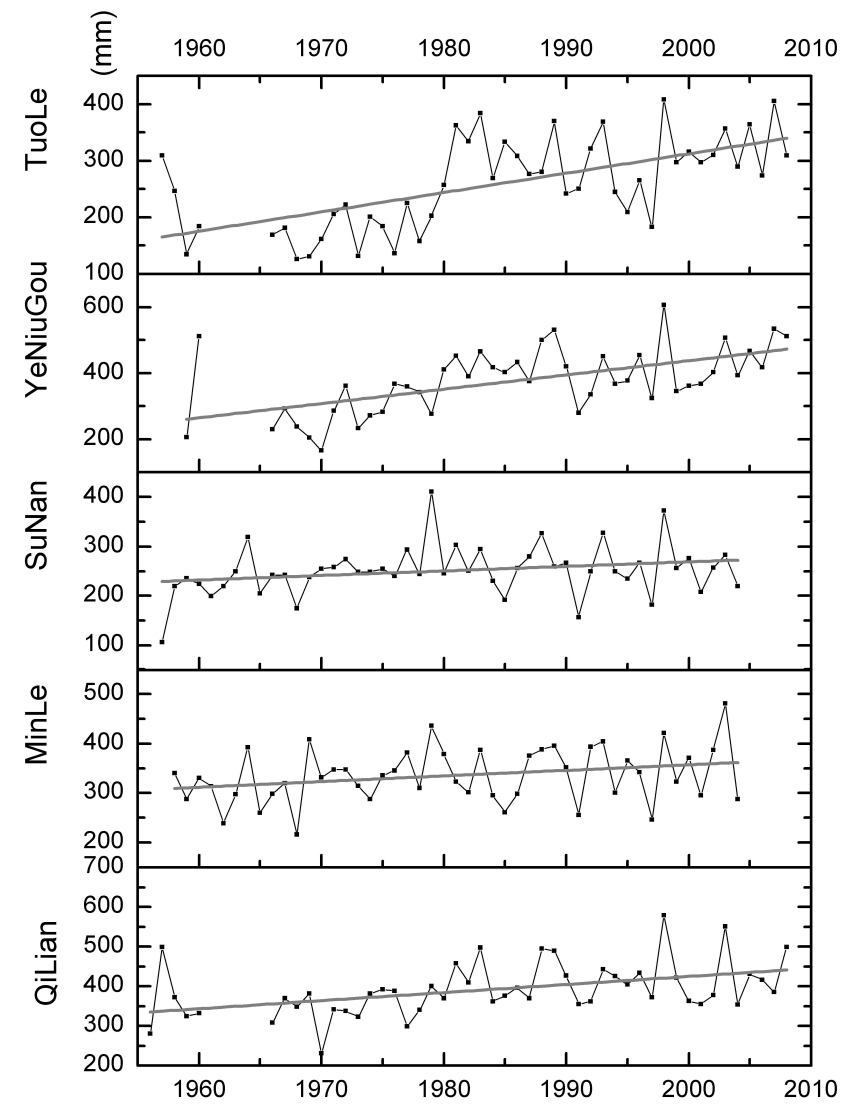

Fig. 5. Annual precipitations of 5 meteorological stations from 1956 to 2008.

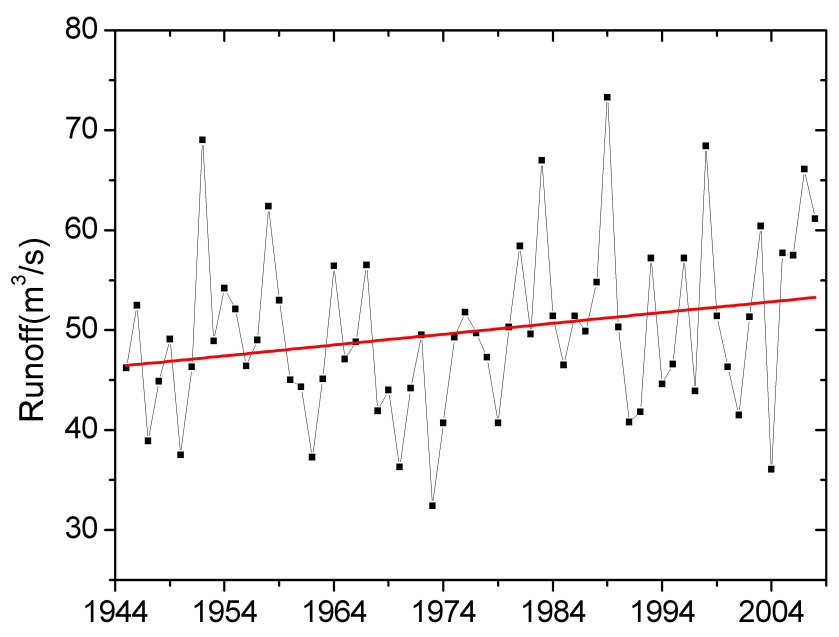

Fig. 6. Average annual runoffs of YingLuoXia hydrologic station.

10 years, while the summer discharge is lower. Overall, the average annual discharge has an increasing trend and the inter-annual variation of peak discharges is large (Figs. 6 and 7). By comparison, discharge of QiLian station which located at middle altitude has an obviously increasing trend

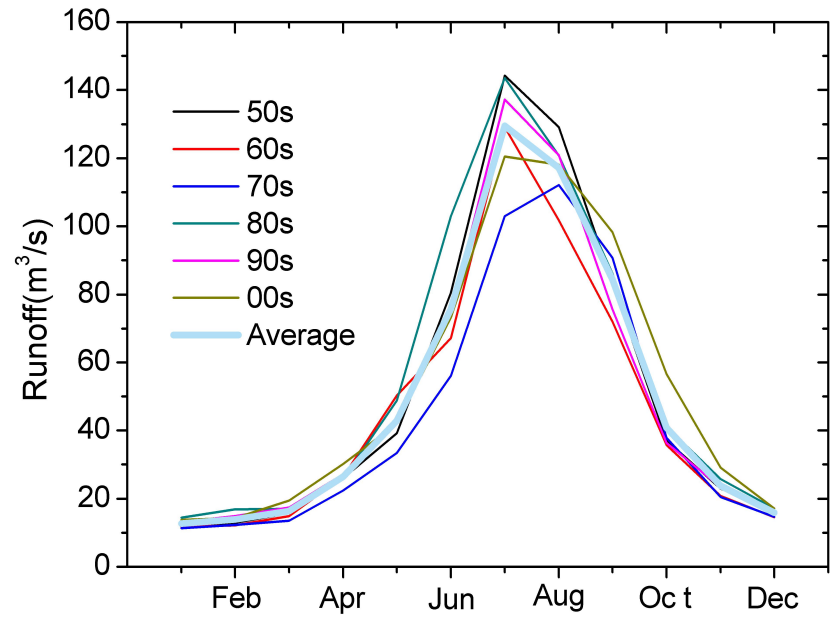

Fig. 7. Average monthly runoff change of YingLuoXia station from 1950 s to present.

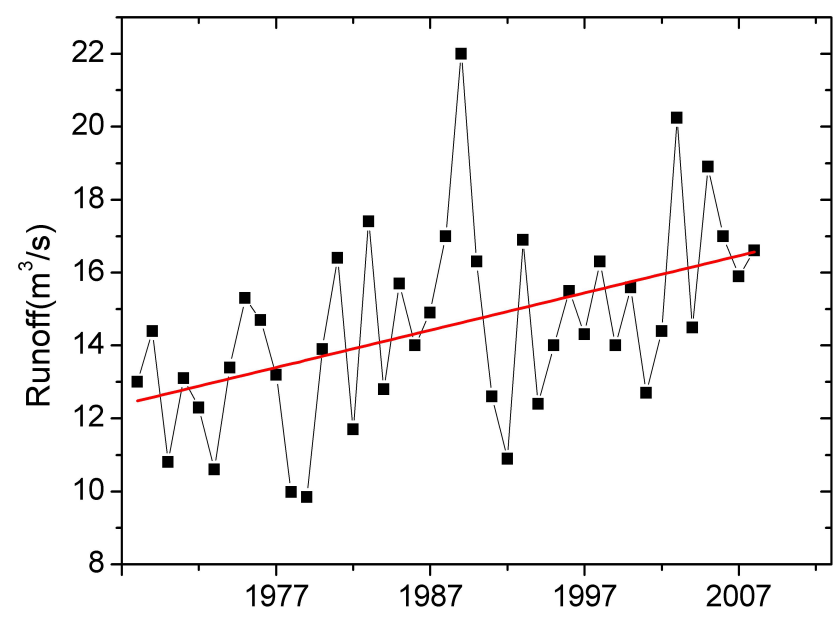

Fig. 8. Average annual runoffs of QiLian station.

(Fig. 8). The maximum discharge occurred at 1989a, and the minimum occurred at 1979a. The comparison of monthly discharges showed that spring discharge has increased obviously from 1970 to present while the autumn discharge shift ahead and decreased (Fig. 9).

Discharge from March to May was released mainly from snowpack in the upper basin of Heihe River. With statistical data of YingLuoXia station and QiLian station from March to May (Figs. 10 and 11), it was found that there are 3 period of the snowmelt runoff increases in this basin: 1950-1970, 1974-1989 and from 1999 to present. On the other hand, the peak spring discharge shifted ahead also, it agrees well with recorded observations (Wang and $\mathrm{Li}, 2001$ ).

\subsection{Snow cover change}

We computed the annual snow cover area and the annual potential snowmelt using the composited 8-days SCA data and 


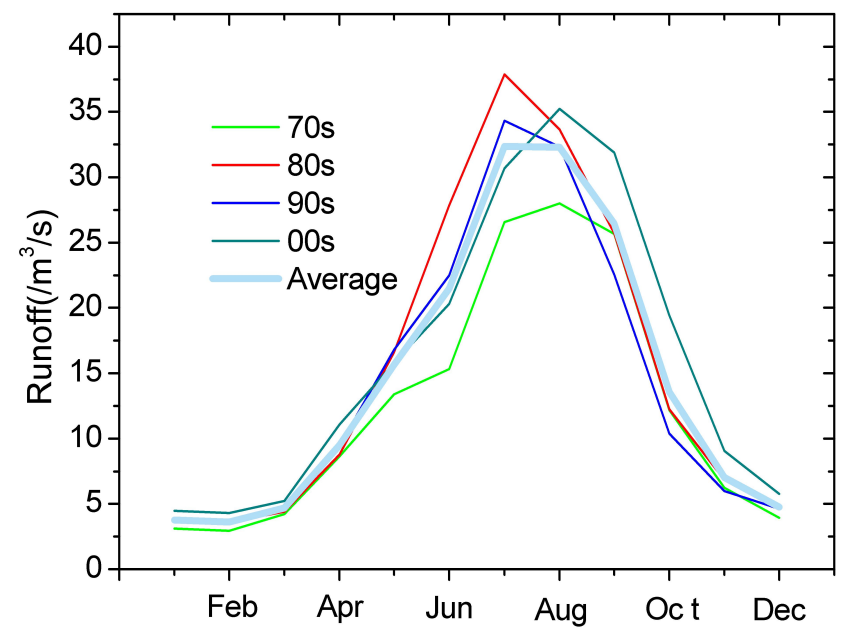

Fig. 9. Average monthly runoff changes of QiLian station.

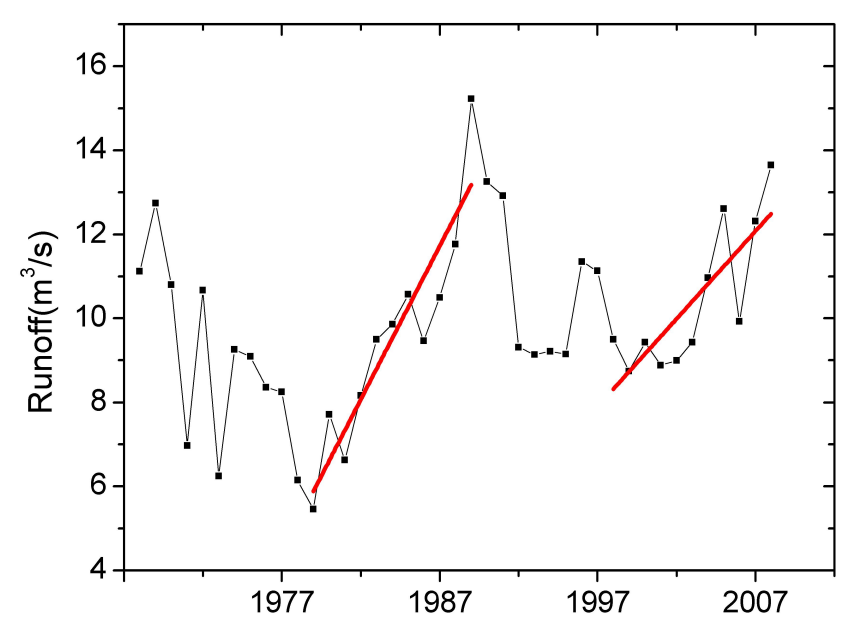

Fig. 10. Monthly spring snowmelt runoff changes of QiLian station (March to May).

air temperature observations from 2000 to 2008 (Fig. 12). Be noted that since the starting time of MODIS SCA data is March 5, 2000, so the annual SCA proportion of the first year 2000 is an incomplete statistics. The SCA proportion, potential snowmelt and air temperature all keeps an increasing trend since 2000 (Fig. 13). The maximum annual SCA proportion is about 0.36 which occurred at 2008 , and the maximum potential snowmelt is about $6.8 \mathrm{~mm}$ which occurred at 2007. Obviously, the potential snowmelt increased with air temperature rising. However, it should be aware that the potential snowmelt not be controlled only by air temperature. Such as the annual air temperature in 2006 is the maximum over the 9 years, but the annual snowmelt is just only $3.7 \mathrm{~mm}$ which is the lowest among all. The basic reason is the interaction between climatic elements in a land surface condition. If air temperature increased, then SCA decreased accordingly. Although the trends of SCA proportion and air temperature keep increasing, the yearly change trend is clearly

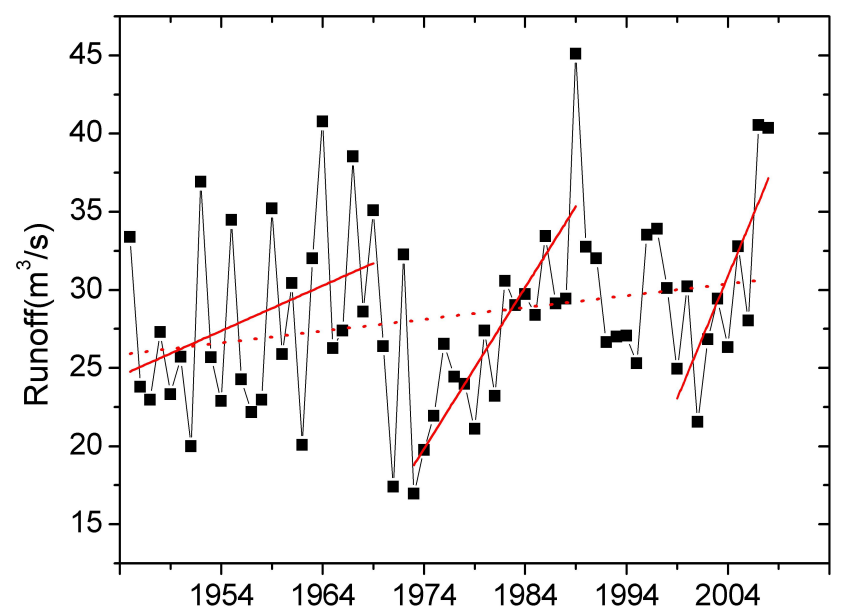

Fig. 11. Monthly spring snowmelt runoff changes of YingLuoXia station (March to May).

different. This can be proved by a simple scatter statistic between annual SCA $\left(\mathrm{SCA}_{\mathrm{avg}}\right)$ and annual air temperature $\left(T_{\text {avg }}\right)$. As a result, the 2 elements are linear correlated obviously (Fig. 14). The result can be formulated as,

$\mathrm{SCA}_{\mathrm{avg}}=0.15-0.18 \times T_{\mathrm{avg}}$

It suggested that potential snowmelt increased with air temperature rising, but not decided only by air temperature. The driven factors include other interactive climatic elements such as SCA.

\subsection{Scenario simulation and analysis of climate change}

SRM model was used to simulate responses of snowmelt runoff to climate change. Several scenarios were designed: single increases of air temperature $\left(+2{ }^{\circ} \mathrm{C},+4{ }^{\circ} \mathrm{C},+6^{\circ} \mathrm{C}\right)$. Firstly, the 2004 snowmelt season was simulated from 5 March to 19 July. Two accuracy criterions, the coefficient recession flow determination and the volume difference are 0.02 and $7.1 \%$ respectively. Then, the responses of snowmelt runoff to climate change were simulated based on this background.

With increases of air temperature $\left(+2{ }^{\circ} \mathrm{C},+4{ }^{\circ} \mathrm{C},+6^{\circ} \mathrm{C}\right)$, the occurred time of peak snowmelt runoff shifted ahead and the discharge increased also (Fig. 15). The first peak discharge happened at 30 April when there is no increase of air temperature. With an increase of $+2{ }^{\circ} \mathrm{C}$, the peak value increased from $102.8 \mathrm{~m}^{3} / \mathrm{s}$ to $197.5 \mathrm{~m}^{3} / \mathrm{s}$ and the start time of snowmelt runoff happened shifted not obviously; With an increase of $+4{ }^{\circ} \mathrm{C}$, the peak discharge increased to $167.1 \mathrm{~m}^{3} / \mathrm{s}$ and the first time of it happened shifted ahead to 24 April; With an increase of $+2{ }^{\circ} \mathrm{C}$, the peak value of snowmelt runoff increased to $240.0 \mathrm{~m}^{3} / \mathrm{s}$ and the first time of it happened shifted ahead to 21 April.

Earlier snowmelt runoff occurring and larger discharge are typical features of responses of snowmelt runoff to air 


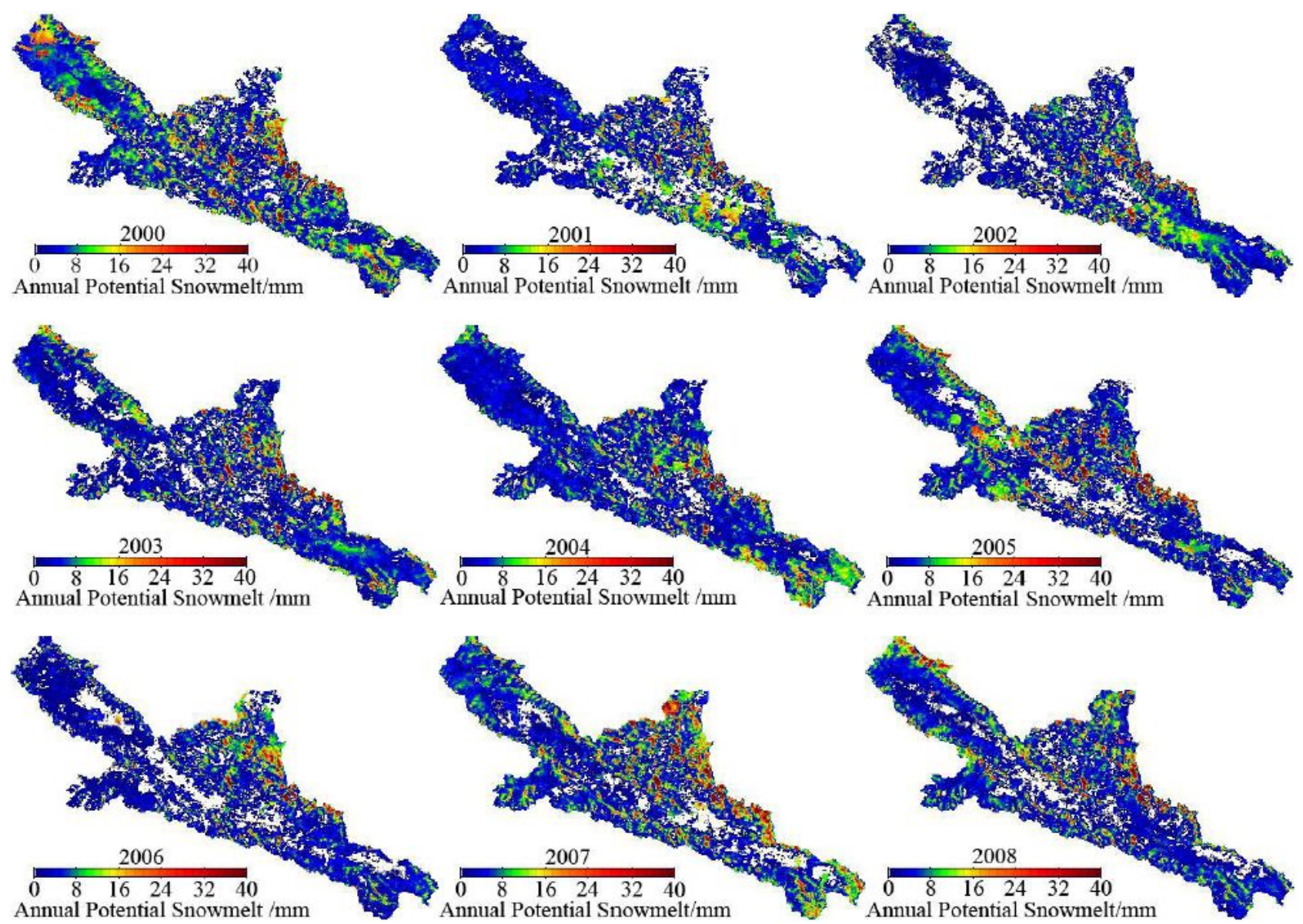

Fig. 12. Annual potential snowmelt distribution in the upper basin of Heihe River from 2000 to 2008.

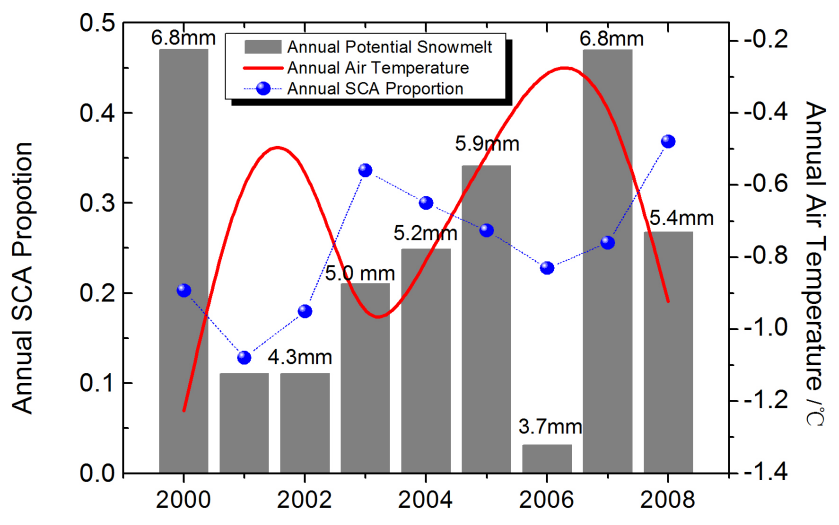

Fig. 13. Change trends of annual SCA proportion, air temperature and potential snowmelt from 2000 to 2008.

temperature increasing, resulted from the analysis of a series of scenarios of air temperature changes. On the other hand, the aftereffect of advanced snowmelt is that the discharge of the later snow season becomes less and then discharge decreased correspondingly. With more increase of temperature,

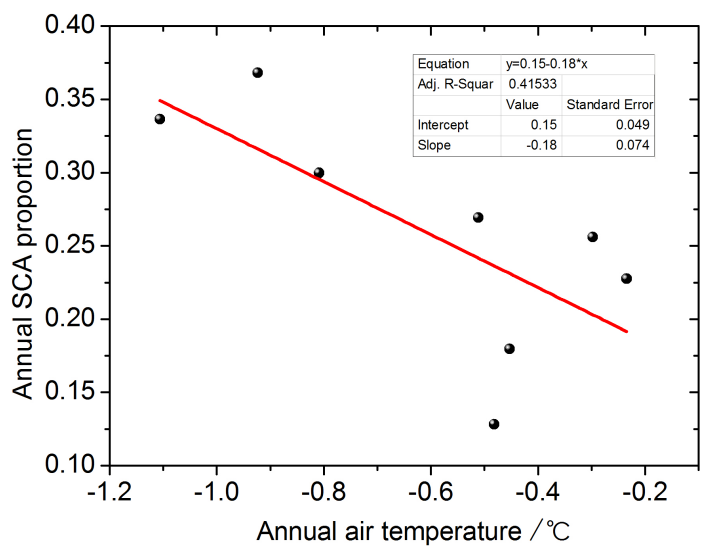

Fig. 14. Linear fit between annual SCA proportion and air temperature. The dataset duration is from 2001 to 2008 .

the discharge in later snow season decreased more. The other aftereffect of it is that the rain season comes ahead because precipitation happened as rain in higher temperature conditions, so the snowmelt confluence processes were affected also. In rain season, influence of temperature increase 


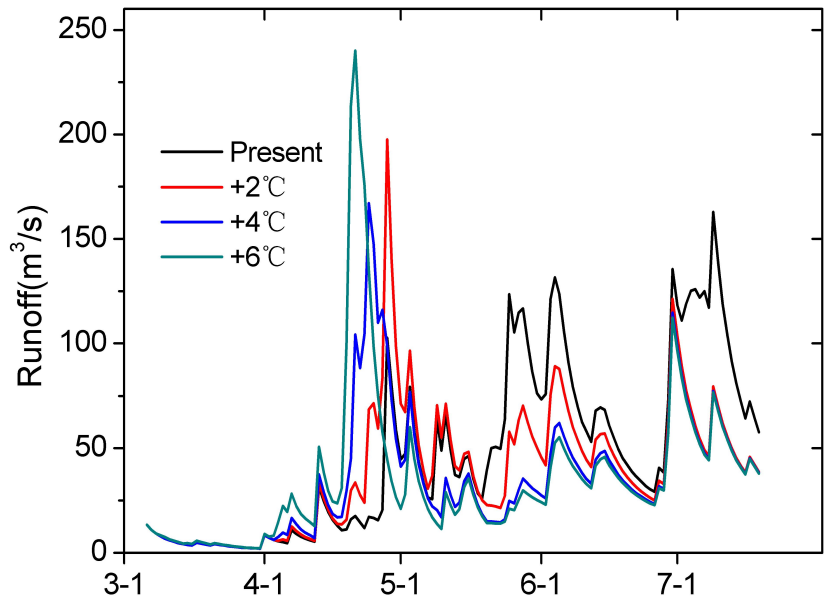

Fig. 15. Responses of snowmelt runoff to air temperature increases, $+2{ }^{\circ} \mathrm{C},+4{ }^{\circ} \mathrm{C},+6{ }^{\circ} \mathrm{C}$.

to runoff is small (Fig. 15). And, average daily runoff of the total snow season, are $47.8 \mathrm{~m}^{3} / \mathrm{s}, 39.4 \mathrm{~m}^{3} / \mathrm{s}, 35.0 \mathrm{~m}^{3} / \mathrm{s}$, $36.1 \mathrm{~m}^{3} / \mathrm{s}$, corresponds to 4 scenarios respectively: present, $+2^{\circ} \mathrm{C},+4^{\circ} \mathrm{C},+6^{\circ} \mathrm{C}$. As a result, the influence of temperature rising to average discharge of snow season is not obvious.

It should be noted that there is a negative relation between air temperature increasing and SCA change. Only air temperature change scenarios were designed there, and the SCA change was not included in it. If we consider the SCA decrease, the simulated average discharge may be lower in the above scenarios. The difficulties to design a scenario including SCA change including: (1) only with information of annual SCA proportion change, it is not realistic to conclude daily or monthly SCA change; (2) the linear relation between SCA and air temperature is just supported in recent 9 years. If we extrapolate the SCA change according to the scenario of $+4{ }^{\circ} \mathrm{C}$ by Eq. (3), the annual SCA proportion value will be negative which is obviously wrong. How SCA change with air temperature in a wider range should be further researched.

\section{Conclusions}

In the upper basin of Heihe River, air temperature has increased gradually in the recent 50 years, and the increase trend is slow from 1956 to 1980a but enlarged after 1980a. The increase of air temperature is about $2.1^{\circ} \mathrm{C}, 2.6^{\circ} \mathrm{C}$ and $2.9^{\circ} \mathrm{C}$ at different weather stations located in the basin. Annual precipitation has increased also and the most marked rise period of precipitation was from 1977 to 1986. In recent 20 years, the increasing trend of snowfall is less obvious but with a large fluctuation. The comparison of monthly discharges showed that snowmelt runoff has increased obviously from 1970 to present while the autumn discharge hydrograph shifted ahead and the volume of it decreased.
An improved snow cover mapping algorithm with NDSI topographic correction and index adjustment was designed to obtain continuous SCA data. The results showed that the annual SCA proportion keeps an increasing trend since 2000, and the maximum is about 0.36 which occurred at 2008 . The potential snowmelt of the basin was defined by a degree-day equation. It increased with air temperature rising, and the maximum is about $6.8 \mathrm{~mm}$ which occurred at 2007 . There is a negative relationship between annual air temperature and SCA proportion from 2000 to 2008.

Snowmelt runoff were simulated using SRM model in different climate change scenarios including : increases of air temperature $\left(+2^{\circ} \mathrm{C},+4{ }^{\circ} \mathrm{C},+6^{\circ} \mathrm{C}\right)$. It was found that snowmelt runoff would occurred earlier and discharges would become larger as the responses of snowmelt runoff to air temperature increasing, and the influence of temperature rising to average discharge of snow season is not obvious.

Acknowledgements. This study was supported by National Natural Science Foundation of China (grant number: 40671040), CAS (Chinese Academy of Sciences) Action Plan for West Development Project "Watershed Allied Telemetry Experimental Research (WATER)" (grant number: KZCX2-XB2-09), and WP6 of FP7 topic ENV.2007.4.1.4.2 "Improving observing systems for water resource management”.

Edited by: X. W. Li

\section{References}

Adam, J. C., Hamlet, A. F., and Lettenmaier, D. P.: Implications of global climate change for snowmelt hydrology in the twenty-first century, Hydrol. Process., 23, 962-972, 2009.

Barnett, T. P., Adam, J. C., and Lettenmaier, D. P.: Potential impacts of a warming climate on water availability in snow-dominated regions, Nature, 438, 303-309, 2005.

Bates, B. C., Kundzewicz, Z. W., Wu, S., and Palutik, J. P.: Climate Change and Water, IPCC Secretariat, Geneva, Technical Paper of the Intergovernmental Panel on Climate Change, 210, 2008.

Civco, D. L.: Topographic normalization of landsat Thematic Mapper digital imagery, Photogramm. Eng. Rem. S., 55, 1303-1309, 1989.

Day, C. A.: Modelling impacts of climate change on snowmelt runoff generation and streamflow across western US mountain basins: a review of techniques and applications for water resource management, Prog. Phys. Geog., 33, 614-633, 2009.

Hall, D. K., Riggs, G. A., and Salomonson, V. V.: Development of methods for mapping global snow cover using Moderate Resolution Imaging Spectroradiometer (MODIS) data, Remote Sens. Environ., 54, 127-140, 1995.

Hall, D. K., Riggs, G. A., Salomonson, V. V., et al.: MODIS snowcover products, Remote Sens. Environ., 83, 181-194, 2002.

Hall, D. K. and Riggs, G. A.: Accuracy assessment of the MODIS snow products, 63rd Eastern Snow Conference, Newark, DE, 1534-1547, 2007. 
Hao, X., Zhang, P., and Wang, J.: Evaluation and comparison of MODIS and VEGETATION Snow Cover products in Northern Xinjiang, China, Remote Sens. Technol. Appl., 24, 603-610, 2009.

Klein, A. G. and Barnett, A. C.: Validation of daily MODIS snow cover maps of the Upper Rio Grande River Basin for the 20002001 snow year, Remote Sens. Environ., 86, 162-176, 2003.

López-Moreno, J. I., Goyette, S., and Beniston, M.: Impact of climate change on snowpack in the Pyrenees: Horizontal spatial variability and vertical gradients, J. Hydrol., 374, 384-396, 2009.

Law, K. H. and Nichol, J.: Topographic correction for differential illumination effects on IKONS satellite imagery, ISPRS Congress, Commission 3, Istanbul, Turkey, 12-23 July, 2004.

Lemke, P., Ren, J., Alley, R. B., Allison, I., Carrasco, J., Flato, G., Fujii, Y., Kaser, G., Mote, P., Thomas, R. H., and Zhang, T.: Observations:Changes in Snow, Ice and Frozen Ground, Contribution of Working Group I to the Fourth Assessment Report of the Intergovernmental Panel on Climate Change, Cambridge, UK and New York, NY, USA, 2007.

Martinec, J., Rango, A., and Roberts, R.: SRM Snowmelt Runoff Model, User's Manual, 2005.

McCabe, G. J. and Wolock, D. M.: Recent Declines in Western U.S. Snowpack in the Context of Twentieth-Century Climate Variability, Earth Interact., 13, 1-15, 2009.

Rauscher, S. A., Pal, J. S., Diffenbaugh, N. S., and Benedetti, M. M.: Future changes in snowmelt-driven runoff timing over the western US, Geophys. Res. Lett., 35, L16703, doi:10.1029/2008g1034424, 2008.
Riggs, G. A., Hall, D. K, and Salomonson, V. V.: MODIS Snow Products User Guide Collection 4, http://modis-snow-ice.gsfc. nasa.gov/sugkc2.html, last access: October 2010, 2006.

Solomon, S., Qin, D., Marquis, M., Averyt, K. B., Tignor, M., and Miller, H. L.: Climate change 2007: the physical science basis: contribution of Working Group I to the Fourth Assessment Report of the Intergovernmental Panel on Climate Change, Cambridge University Press, Cambridge, New York, 2007.

Stewart, I. T., Cayan, D. R., and Dettinger, M. D.: Changes in snowmelt runoff timing in western North America under a "business as usual" climate change scenario, Climatic Change, 62, 217-232, 2004.

Tekeli, A. E., Akyurek, Z., Sorman, A. A., Sensoy, A., and Sorman, A. U.: Using MODIS snow cover maps in modeling snowmelt runoff process in the eastern part of Turkey, Remote Sens. Environ., 97, 216-230, 2005.

Wang, J. and Li, W.: Establishing snowmelt runoff simulating model using remote sensing data and GIS in the west of China, Int. J. Remote. Sens., 22, 3267-3274, 2001.

Wang, J. and Wang, L. H.: A review on snow cover and snowmelt runoff simulating using remote sensing data sets in China, P. Soc. Photo-Opt. Ins., 4894, 446-455, 2003.

Wang, J. and Li, S.: Effect of climatic change on snowmelt runoffs in mountainous regions of inland rivers in Northwestern China, Sci. China Ser. D, 49, 881-888, 2006. 